\title{
Insulin Production Rate Following Glucose Ingestion Estimated by Splanchnic C-Peptide Output in Normal Man
}

\author{
W. Waldhäusl, P. Bratusch-Marrain, S. Gasic, A. Korn, and P. Nowotny \\ 1. Medizinische Universitätsklinik, Abteilung für klinische Endokrinologie und Diabetes Mellitus
}

\begin{abstract}
Summary. Insulin production rate has been estimated in healthy male volunteers $(n=16)$, and evaluated with respect to splanchnic glucose exchange. Insulin production rate was calculated from splanchnic immunoreactive C-peptide output. C-peptide secretion was estimated by the hepatic venous catheter technique both in the basal state and for $2 \mathrm{~h}$ following ingestion of various glucose loads $(0,12.5,25,50$, 75 , and $100 \mathrm{~g}$ ). The results demonstrate a basal insulin production rate of $0.017 \pm 0.002 \mathrm{U} / \mathrm{min}$ (mean \pm $\mathrm{SEM}$ ) or $2.04 \mathrm{U} / 2 \mathrm{~h}$. Values rose in a dose dependent manner from $2.6 \pm 1.1 \mathrm{U} / 2 \mathrm{~h}$ after ingestion of $12.5 \mathrm{~g}$ of glucose to $10.8 \pm 1.1 \mathrm{U} / 2 \mathrm{~h}$ following a glucose load of $100 \mathrm{~g}$. Insulin retention by the liver was estimated at $0.012 \pm 0.001 \mathrm{U} / \mathrm{min}$ in the basal state, and ranged from $47-85 \%(70 \pm 2 \%)$ of production following an oral glucose load. It was also demonstrated 1) that the relative splanchnic glucose output was inversely related to the amount of ingested glucose, and reached a minimum when glucose in excess of $50 \mathrm{~g}$ was ingested; and 2) that hepatic glucose retention was directly proportional to insulin production rate $(r=0.83 ; \mathrm{p}<0.001 ; \mathrm{n}=$ $15)$. It is suggested that the adaptive capacity of the splanchnic bed to retain glucose depending on the amount of ingested glucose guarantees that splanchnic glucose output fluctuates in healthy man only within a narrow range.
\end{abstract}

Key words: Insulin production rate, splanchnic Cpeptide output, hepatic insulin retention, splanchnic metabolism, man, glucose.

Pancreatic insulin production has been studied previously in man by estimating the metabolic clearance of insulin $[1,2]$. The valid use of radioactive tracer for this purpose has been questioned, since it is required that the kinetics of labelled and unlabelled hormone be the same [1]. Therefore unlabelled insulin has been used to study the kinetics of insulin [3]. However, direct measurements of the splanchnic output of immunoreactive insulin (IRI) are of no value in determining pancreatic insulin production rate (IPR), since a large fraction of insulin is extracted by the liver on first pass [4-10]. In contrast to the latter observation it has been shown that C-peptide almost completely escapes the splanchnic bed $[11,12]$, and that C-peptide and insulin are secreted by the B-cell in equimolar concentrations [13].

The present study was therefore designed to calculate the pancreatic insulin production rate from the difference in hepatic venous and arterial immunoreactive C-peptide (C-peptide) concentrations multiplied by the estimated hepatic plasma flow (EHPF) both in the basal state and following glucose ingestion. This approach was adopted since the determination of insulin and C-peptide is not feasible in the portal blood of healthy man. Insulin retention by the liver was determined as the difference between insulin production rate as calculated from Cpeptide values and the splanchnic output of IRI. The effects of ingested glucose on splanchnic glucose output (SGO) were also investigated to evaluate the interrelationship between an oral glucose load, insulin production rate and the amount of glucose assimilated by the splanchnic bed.

\section{Material and Methods}

\section{Subjects}

Subjects were 16 healthy male volunteers, between 19 and 29 years of age. All were within 10 per cent of ideal body weight (based on Metropolitan Life Insurance Tables, 1959) and not taking any drugs at the time of the study. None was diabetic or gave a 
Table 1. Basal concentrations of blood glucose, serum IRI and Cpeptide in arterial blood (A) and hepatic venous (HV) effluent. Their splanchnic output was calculated individually by the product of the arterio-hepatic venous difference (HV-A) times the EHBF (estimated hepatic blood flow) for glucose, or the EHPF for IRI and C-peptide. Insulin production rate $(\mathrm{mU} / \mathrm{min})$ was estimated from splanchnic C-peptide output. Mean $\pm \operatorname{SEM}(\mathrm{n}=16)$

\begin{tabular}{|c|c|c|c|}
\hline Time (min) & -30 & -15 & 0 \\
\hline $\mathrm{EHBF}(\mathrm{ml} / \mathrm{min})$ & $1455 \pm 72$ & $1372 \pm 73$ & $1426 \pm 86$ \\
\hline $\mathrm{EHPF}(\mathrm{ml} / \mathrm{min})$ & $830 \pm 41$ & $784 \pm 42$ & $813 \pm 50$ \\
\hline Blood glucose & $93 \pm 2$ & $92 \pm 8$ & $94 \pm 2$ \\
\hline$(\mathrm{mg} / 100 \mathrm{ml})$ & $103 \pm 3$ & $102 \pm 2$ & $103 \pm 2$ \\
\hline HV-A & $10 \pm 2$ & $10 \pm 1$ & $9 \pm 2$ \\
\hline $\begin{array}{l}\text { Splanchnic glucose } \\
\text { output }(\mathrm{mg} / \mathrm{min})\end{array}$ & $139 \pm 18$ & $125 \pm 12$ & $135 \pm 27$ \\
\hline IRI $(\mathrm{pmol} / \mathrm{l})$ & $66 \pm 6$ & $65 \pm 7$ & $60 \pm 6$ \\
\hline HV & $100 \pm 11$ & $97 \pm 9$ & $97 \pm 8$ \\
\hline HV-A & $34 \pm 6$ & $32 \pm 5$ & $37 \pm 4$ \\
\hline $\begin{array}{l}\text { Splanchnic-IRI-output } \\
(\mathrm{pmol} / \mathrm{min})\end{array}$ & $25.2 \pm 3.6$ & $23.8 \pm 2.9$ & $29.5 \pm 4.3$ \\
\hline$(\mathrm{mU} / \mathrm{min})$ & $3.5 \pm 0.5$ & $3.3 \pm 0.4$ & $4.1 \pm 0.6$ \\
\hline C-peptide $(\mathrm{pmol} / \mathrm{l}) \quad \mathrm{A}$ & $642 \pm 37$ & $619 \pm 33$ & $622 \pm 36$ \\
\hline $\mathrm{HV}$ & $808 \pm 50$ & $761 \pm 43$ & $775 \pm 50$ \\
\hline HV-A & $166 \pm 17$ & $142 \pm 20$ & $152 \pm 17$ \\
\hline $\begin{array}{l}\text { Splanchnic-C-peptide- } \\
\text { output (pmol/min) }\end{array}$ & $131 \pm 13$ & $111 \pm 14$ & $121 \pm 15$ \\
\hline $\begin{array}{l}\text { Insulin production } \\
\text { rate }(\mathrm{mU} / \mathrm{min})\end{array}$ & $18 \pm 2$ & $15 \pm 2$ & $17 \pm 2$ \\
\hline
\end{tabular}

history of liver disease. Liver function tests were normal. All had an oral glucose tolerance test before the study with capillary glucose values $<160 \mathrm{mg} / 100 \mathrm{ml}$ at $60 \mathrm{~min},<140 \mathrm{mg} / 100 \mathrm{ml}$ at 90 $\mathrm{min}$, and $<120 \mathrm{mg} / 100 \mathrm{ml}$ at $120 \mathrm{~min}$. For at least three days prior to the study a diet rich in carbohydrates $(250-300 \mathrm{~g})$ was ingested by all subjects. The nature, purpose and possible risks involved in the study were carefully explained to all subjects prior to obtaining their voluntary consent to participate.

\section{Procedures}

The studies were performed in the morning after an overnight fast $(12-14 \mathrm{~h})$. The procedure employed for the hepatic venous and arterial catheterization was similar to that described previously [14] with catheters inserted percutaneously into a peripheral vein, a femoral artery and through a femoral vein into a right sided hepatic vein under fluoroscopic control. After the catheters were in place arterial and hepatic venous blood was drawn at $7.5 \mathrm{~min}$ intervals both for a $30 \mathrm{~min}$ basal control period and for two $\mathrm{h}$ after oral glucose administration. Oral glucose (glucose monohydrate $55 \mathrm{~g} / 130 \mathrm{ml}$ corresponding to $50 \mathrm{~g}$ glucose, Boehringer-Mannheim, FRG) was ingested over three minutes after the control period followed by $100 \mathrm{ml}$ of plain water. Glucose loads of $0(\mathrm{n}=$ $1), 12.5 \mathrm{~g}(\mathrm{n}=3), 25 \mathrm{~g}(\mathrm{n}=3), 50 \mathrm{~g}(\mathrm{n}=3), 75 \mathrm{~g}(\mathrm{n}=1)$, and $100 \mathrm{~g}(\mathrm{n}=5)$ were administered.

Glucose was analyzed in whole blood using the hexokinase reaction [15]. Serum concentrations of insulin [16] and C-peptide (Byk-Mallinckrodt) were determined radioimmunologically. The calculated interassay sensitivity $(2 \mathrm{SD}, \mathrm{n}=20$ ) and coefficient of variation $(1 \mathrm{SD} ; \mathrm{V} \% ; \mathrm{n}=20)$ for the estimation of insulin was $1.7 \mu \mathrm{U} / \mathrm{ml}(\mathrm{V}=8.5 \%)$ for $10 \mu \mathrm{U} / \mathrm{ml}, 5.6 \mu \mathrm{U} / \mathrm{ml}(\mathrm{V}=7.6 \%)$ for $37 \mu \mathrm{U} / \mathrm{ml}$, and $30.7 \mu \mathrm{U} / \mathrm{ml}(\mathrm{V}=8.6 \%)$ for $174 \mu \mathrm{U} / \mathrm{ml}$. The calculated sensitivity for the $C$-peptide radioimmunoassay $(n=20)$ was $0.17 \mathrm{ng} / \mathrm{ml}(\mathrm{V}=5.3 \%)$ for $1.7 \mathrm{ng} / \mathrm{ml}$. Values for insulin $(1 \mu \mathrm{U} / \mathrm{ml}$ equalling $7.3 \mathrm{pmol} / \mathrm{l})$ and C-peptide $(1 \mathrm{ng} / \mathrm{ml}$ equalling $331 \mathrm{pmol} / \mathrm{l}$ ) in tables and figures were expressed in molarities.

The methods estimating splanchnic exchange of glucose by means of the hepatic venous catheter technique using indocyanine green dye [17] and the constant infusion technique [18] for splanchnic blood and plasma flow measurements have been described recently [14]. Splanchnic glucose retention $(\mathrm{g} / 2 \mathrm{~h})$ was calculated as the amount of ingested glucose minus splanchnic glucose output above basal per $2 \mathrm{~h}$.

Splanchnic insulin (nmol/2 h) and C-peptide ( $\mathrm{nmol} / 2 \mathrm{~h}$ ) output were calculated from their respective difference in hepatic venous and arterial concentrations multiplied by the estimated hepatic plasma flow (EHPF). Insulin production rate (IPR, units/2 h) was calculated from splanchnic $C$-peptide output assuming an equimolar release of C-peptide and insulin by the B-cell [13], and neglecting the minimal $\mathrm{C}$-peptide retention by the liver $[11,12]$. The estimation of IPR refers to the international insulin standard (1 mg $=24 \mathrm{IU}$ ), and to the molecular weight of human insulin (5734 Dalton [19]) and of human C-peptide (3021 Dalton [20]). Insulin retention by the liver was determined as the difference between the IPR and splanchnic-IRI-output.

Data in the text and figures are presented as the mean \pm SEM. The unpaired Student t-test and calculation of the coefficient of correlation were employed for statistical analysis.

\section{Results}

\section{Basal Concentrations in Arterial Blood and Hepatic Venous Effluent, and Splanchnic Exchange of Blood Glucose, Serum IRI, and C-Peptide (Table 1)}

Prior to glucose ingestion, values of splanchnic exchange of glucose, insulin and C-peptide were studied for $30 \mathrm{~min}$. During this period mean $(\mathrm{n}=16)$ arterial and hepatic venous values fluctuated only to a small extent. Ranges were for splanchnic glucose output 34 to $266 \mathrm{mg} / \mathrm{min}$, for splanchnic insulin output 10.4 to $40.9 \mathrm{pmol} / \mathrm{min}$, and for splanchnic Cpeptide output 54.6 to $254 \mathrm{pmol} / \mathrm{min}$. Basal insulin production rate as calculated from splanchnic C-peptide output was 7.5 to $35 \mathrm{mU} / \mathrm{min}$ (mean $17 \pm 2 \mathrm{mU}$ / $\min )$.

\section{Estimated Hepatic Plasma Flow, Arterial Concentrations of Glucose, Insulin and C-Peptide}

EHPF increased 15 min after oral glucose ingestion in all groups and reached peak values of 11 to 49 per cent above basal at 15 to $37.5 \mathrm{~min}$. A secondary increase in EHPF was observed at $120 \mathrm{~min}$ in subjects receiving 75 and $100 \mathrm{~g}$ of glucose.

The arterial blood glucose levels rose by 25 to 102 per cent following oral glucose ingestion reaching peak levels at 22.5 to $52.5 \mathrm{~min}$. Arterial blood glucose returned to basal levels within two hours only in individuals receiving $12.5 \mathrm{~g}$ or $25 \mathrm{~g}$ of oral glucose. In subjects receiving 50 to $100 \mathrm{~g}$ of glucose arterial 
Table 2. Estimated hepatic plasma flow ( $\mathrm{ml} / \mathrm{min}$ ), and arterial concentrations of glucose $(\mathrm{mg} / 100 \mathrm{ml})$, insulin (pmol/l) and C-peptide (pmol/l) in healthy male subjects ingesting $100 \mathrm{~g}$ glucose. Basel values represent the mean \pm SEM of five observations in each subject during 30 min preceding glucose loading

\begin{tabular}{|c|c|c|c|c|c|c|c|c|c|}
\hline Time (min) & Basal & 15 & 30 & 45 & 60 & 75 & 90 & 105 & 120 \\
\hline $\mathrm{EHPF}(\mathrm{ml} / \mathrm{min})$ & $820 \pm 38$ & $1209 \pm 65$ & $1087 \pm 93$ & $1219 \pm 235$ & $1018 \pm 96$ & $933 \pm 44$ & $1035 \pm 49$ & $963 \pm 64$ & $1176 \pm 192$ \\
\hline $\begin{array}{l}\text { Arterial glucose } \\
(\mathrm{mg} / 100 \mathrm{ml})\end{array}$ & $91 \pm 4$ & $126 \pm 5$ & $142 \pm 20$ & $178 \pm 16$ & $176 \pm 13$ & $176 \pm 9$ & $173 \pm 16$ & $173 \pm 27$ & $155 \pm 25$ \\
\hline $\begin{array}{l}\text { Arterial IRI } \\
(\mathrm{pmol} / \mathrm{l})\end{array}$ & $77 \pm 15$ & $298 \pm 109$ & $486 \pm 160$ & $603 \pm 203$ & $589 \pm 182$ & $748 \pm 203$ & $734 \pm 196$ & $603 \pm 153$ & $501 \pm 167$ \\
\hline $\begin{array}{l}\text { Arterial C-peptide } \\
(\mathrm{pmol} / \mathrm{l})\end{array}$ & $641 \pm 69$ & $1410 \pm 245$ & $2072 \pm 417$ & $2598 \pm 579$ & $2863 \pm 655$ & $3250 \pm 695$ & $3575 \pm 608$ & $3413 \pm 467$ & $3109 \pm 407$ \\
\hline
\end{tabular}

Table 3. Splanchnic glucose output, splanchnic retention of ingested glucose (SG-retention), splanchnic insulin output, and splanchnic Cpeptide output over $120 \mathrm{~min}$ following oral glucose loading $(12.5,25,50,75$ and $100 \mathrm{~g})$. Insulin production rate (units) was estimated from total splanchnic C-peptide output. Splanchnic insulin retention was calculated as insulin production rate minus splanchnic insulin output. Basal values were calculated for $2 \mathrm{~h}$ from the mean of three to five observations in each subject during 30 min preceding glucose loading, and the mean of all data in one subject without glucose loading. Thus all values are presented as mean \pm SEM per $2 \mathrm{~h}$, p vs. preceding group (excluding $75 \mathrm{~g}$ ). ${ }^{\mathrm{a}} \mathrm{p}<0.05$; ${ }^{\mathrm{b}} \mathrm{p}<0.01 ;{ }^{\mathrm{c}} \mathrm{p}<0.0025 ;{ }^{\mathrm{d}} \mathrm{p}<0.0005$; ${ }^{\mathrm{e}} \mathrm{p}$ vs. 12.5 and $25 \mathrm{~g}$; ${ }^{\mathrm{f}}$ above basal

\begin{tabular}{|c|c|c|c|c|c|c|}
\hline \multirow[b]{2}{*}{$\mathrm{n}$} & \multicolumn{6}{|c|}{ Oral glucose load (g) } \\
\hline & $\begin{array}{l}\text { Basal } \\
(16)\end{array}$ & $\begin{array}{l}12.5 \\
(3)\end{array}$ & $\begin{array}{l}25 \\
(3)\end{array}$ & $\begin{array}{l}50 \\
(3)\end{array}$ & $\begin{array}{l}75 \\
(1)\end{array}$ & $\begin{array}{l}100 \\
(5)\end{array}$ \\
\hline Splanchnic glucose output (g) & $15.1 \pm 1.3$ & $9.0 \pm 2.0^{2}$ & $10.0 \pm 3.8^{f}$ & $12.3 \pm 1.3^{f}$ & $20^{\mathrm{f}}$ & $24.7 \pm 1.0^{\mathrm{d}, \mathrm{f}}$ \\
\hline Splanchnic glucose retention $(\mathrm{g})$ & - & $3.5 \pm 2.0$ & $15.0 \pm 3.8^{\mathrm{a}}$ & $38.0 \pm 1.3^{\mathrm{c}}$ & 55 & $75.3 \pm 1.0^{\mathrm{d}}$ \\
\hline $\begin{array}{r}\text { Splanchnic insulin output (nmol) } \\
\text { (Units) }\end{array}$ & $\begin{array}{l}3.36 \pm 0.29 \\
0.46 \pm 0.04\end{array}$ & $\begin{array}{l}3.34 \pm 1.5 \\
0.46 \pm 0.22\end{array}$ & $\begin{array}{l}5.6 \pm 2.0 \\
0.79 \pm 0.28\end{array}$ & $\begin{aligned} 13.2 \pm & \pm 2.7^{\mathrm{a}} \\
1.84 \pm & 0.38^{\mathrm{a}}\end{aligned}$ & $\begin{array}{l}21.9 \\
3.05\end{array}$ & $\begin{aligned} 21.8 & \pm 3.7^{\mathrm{b}, \mathrm{e}} \\
3.02 & \pm 0.51^{\mathrm{b}, \mathrm{e}}\end{aligned}$ \\
\hline Splanchnic C-peptide output (nmol) & $14.9 \pm 1.32$ & $17.6 \pm 6.3$ & $23.9 \pm 5.1$ & $49.0 \pm 10$ & 56.2 & $77.8 \pm 12.2^{\mathrm{a}, \mathrm{b}, \mathrm{e}}$ \\
\hline Insulin production rate (Units) & $2.04 \pm 0.24$ & $2.6 \pm 1.1$ & $3.2 \pm 0.7$ & $6.8 \pm 1.4$ & 7.8 & $10.8 \pm 1.7^{\mathrm{a}, \mathrm{b}, \mathrm{e}}$ \\
\hline $\begin{array}{r}\text { Splanchnic insulin retention (nmol) } \\
\text { (Units) }\end{array}$ & $\begin{array}{c}11.3 \pm 0.9 \\
1.56 \pm 0.12\end{array}$ & $\begin{aligned} 14.4 & \pm 5.8 \\
2.0 & \pm 0.8\end{aligned}$ & $\begin{aligned} 18.3 & \pm 3.6 \\
2.6 & \pm 0.5\end{aligned}$ & $\begin{array}{r}35.8 \pm 10.8 \\
4.9 \pm 1.5\end{array}$ & $\begin{array}{r}34.3 \\
4.7\end{array}$ & $\begin{aligned} 56.0 & \pm 10.8^{\mathrm{b}, \mathrm{e}} \\
7.8 & \pm 1.5^{\mathrm{b}, \mathrm{e}}\end{aligned}$ \\
\hline
\end{tabular}

blood glucose was still above basal levels at the end of the observation period.

Arterial IRI rose as expected two- to ninefold depending upon the amount of ingested glucose. Peak levels of IRI were reached at 15 min when $12.5 \mathrm{~g}$ of glucose and at $75 \mathrm{~min}$ when $100 \mathrm{~g}$ of glucose were administered.

Serum C-peptide concentrations also rose immediately following glucose ingestion. C-peptide levels after different glucose loads reached at 30 to $90 \mathrm{~min}$ their respective peaks which were two- to fivefold above basal. At $120 \mathrm{~min}$ C-peptide levels were still two- to fourfold above their respective basal concentration. The data for EHPF, and arterial concentrations of glucose, IRI and C-peptide obtained in the group receiving $100 \mathrm{~g}$ glucose are shown in Table 2.

\section{Splanchnic Insulin and Glucose Metabolism} (Table 3)

The influence of an oral glucose load on splanchnic glucose output, splanchnic insulin and C-peptide out- put, and the splanchnic retention of glucose and insulin are shown in Table 3 . Basal splanchnic glucose output was $126 \pm 11 \mathrm{mg} / \mathrm{min}$, or $15.1 \pm 1.3 \mathrm{~g} / 2 \mathrm{~h}$. The cumulative splanchnic glucose output above basal during the two hour observation period $(\mathrm{g} / 2 \mathrm{~h})$ rose from $9.0 \pm 2.0 \mathrm{~g}(\mathrm{n}=3)$ following a glucose load of $12.5 \mathrm{~g}$ to $24.7 \pm 1.0 \mathrm{~g}(\mathrm{n}=5)$ when $100 \mathrm{~g}$ of glucose were administered $(\mathrm{p}<0.0005)$. Conversely, net splanchnic glucose retention rose from $3.5 \pm$ $2.0 \mathrm{~g}$ to $75.3 \pm 1.0 \mathrm{~g}$ per $2 \mathrm{~h}$. The amount of glucose retained by the splanchnic bed rose significantly from dose to dose when compared with the value of the respective preceding group.

Splanchnic IRI output in the basal state was 3.84 $\pm 0.33 \mathrm{mU} / \mathrm{min}$ corresponding to $0.46 \pm 0.04$ units of immunoreactive insulin per $2 \mathrm{~h}$. Splanchnic IRI output remained unchanged after $12.5 \mathrm{~g}$ of oral glucose, and rose upon ingestion of $100 \mathrm{~g}$ glucose to $3.02 \pm 0.51 \mathrm{U} / 2 \mathrm{~h}(\mathrm{p}<0.01)$.

Splanchnic C-peptide output in the basal state was $14.9 \pm 1.32 \mathrm{nmol} / 2 \mathrm{~h}$. The cumulative splanchnic C-peptide output rose consistently during the two hour observation period from $17.6 \pm 6.3 \mathrm{nmol} / 2 \mathrm{~h}$ 


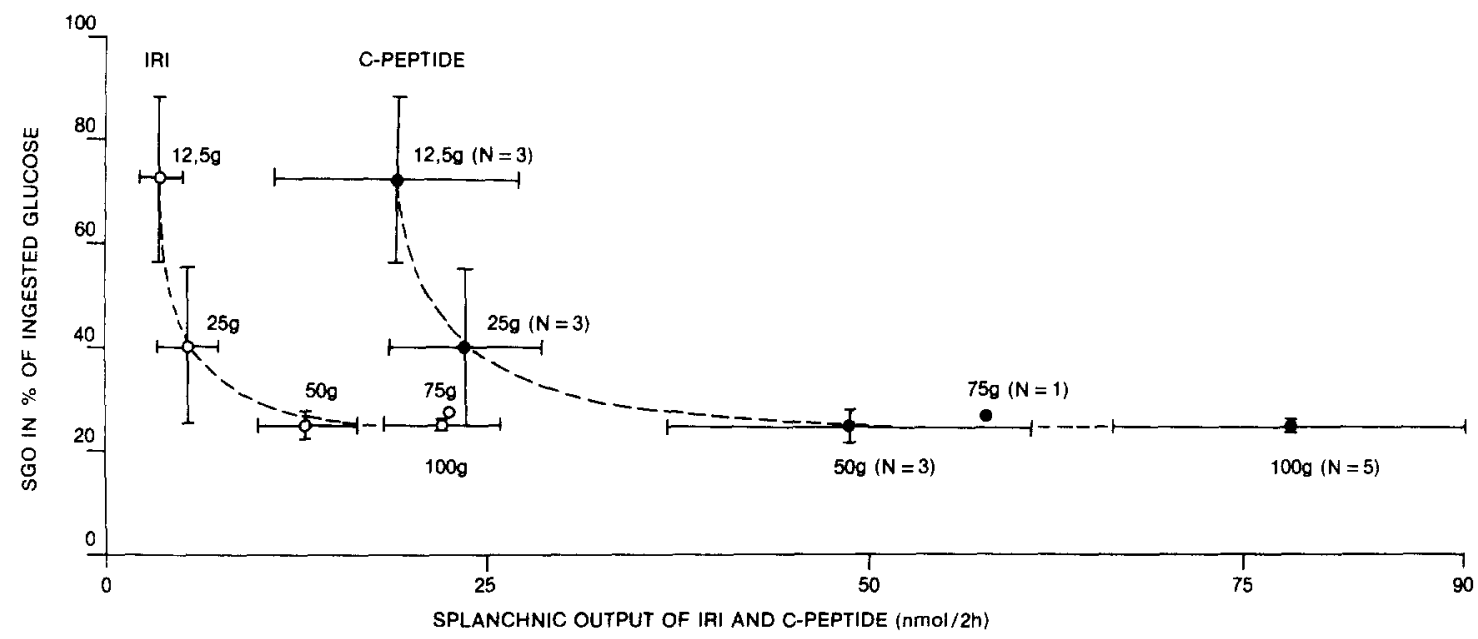

Fig. 1. Relation of splanchnic glucose output (SGO) in per cent of ingested glucose, and splanchnic output of IRI (O) and C-peptide (•) $(\mathrm{nmol} / 2 \mathrm{~h})$ in healthy male subjects. Glucose loads were $12.5 \mathrm{~g}(\mathrm{n}=3), 25 \mathrm{~g}(\mathrm{n}=3), 50 \mathrm{~g}(\mathrm{n}=3), 75 \mathrm{~g}(\mathrm{n}=1)$, and $100 \mathrm{~g}(\mathrm{n}=5)$. Values are given as mean $\pm \mathrm{SEM}$

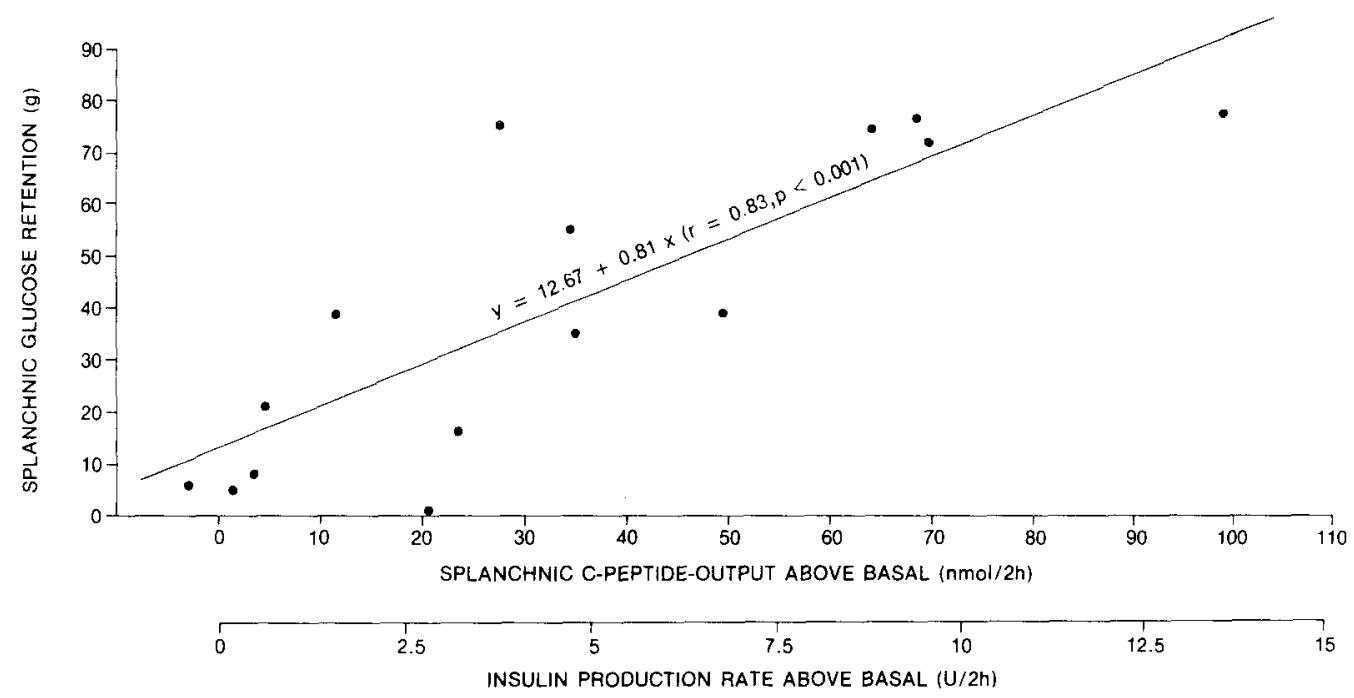

Fig. 2. Correlation between splanchnic glucose retention $(\mathrm{g} / 2 \mathrm{~h})$ and splanchnic C-peptide output above basal (nmol/2 h), and the insulin production rate above basal (units $/ 2 \mathrm{~h}$ ) in healthy male subjects $(\mathrm{n}=15)$ ingesting various amounts of glucose. Glucose loads were $12.5 \mathrm{~g}$ $(\mathrm{n}=3), 25 \mathrm{~g}(\mathrm{n}=3), 50 \mathrm{~g}(\mathrm{n}=3), 75 \mathrm{~g}(\mathrm{n}=1)$, and $100 \mathrm{~g}(\mathrm{n}=5)$

$(\mathrm{n}=3$ ) following a glucose load of $12.5 \mathrm{~g}$ to $77.8 \pm$ $12.2 \mathrm{nmol} / 2 \mathrm{~h}(\mathrm{n}=5)$ when $100 \mathrm{~g}$ of glucose were administered $(\mathrm{p}<0.01)$.

Calculation of the insulin production rate from splanchnic C-peptide output on the basis of an equimolar release of $\mathrm{C}$-peptide and insulin by the pancreatic $\mathrm{B}$-cell revealed a basal production rate of insulin of $0.017 \pm 0.002 \mathrm{U} / \mathrm{min}$, or of $2.04 \pm 0.24 \mathrm{U} /$ $2 \mathrm{~h}$. Insulin production rate rose in a dose dependent manner from $2.6 \pm 1.1 \mathrm{U} / 2 \mathrm{~h}$ after ingestion of $12.5 \mathrm{~g}$ of glucose to $10.8 \pm 1.1 \mathrm{U} / 2 \mathrm{~h}$ following a glucose load of $100 \mathrm{~g}(\mathrm{p}<0.01)$.

Calculated splanchnic insulin retention in the basal state was $11.3 \pm 0.9 \mathrm{nmol} / 2 \mathrm{~h}$ corresponding to $1.56 \pm 0.12 \mathrm{U} / 2 \mathrm{~h}$. Splanchnic insulin retention rose to $14.4 \pm 5.8 \mathrm{nmol} / 2 \mathrm{~h}$ after $12.5 \mathrm{~g}$ of oral glucose, and to $56.0 \pm 10.8 \mathrm{nmol} / 2 \mathrm{~h}$ when $100 \mathrm{~g}$ of glucose were ingested. The relative amount of insulin retained by the splanchnic bed was $75 \pm 2 \%$ during basal conditions, and $70 \pm 3 \%$ (range $47-85 \%$ ) following oral glucose ingestion.

The relation between splanchnic glucose output (SGO) in per cent of ingested glucose, and the splanchnic output of IRI and C-peptide in $\mathrm{nmol} / 2 \mathrm{~h}$ is shown in Figure 1. It is apparent that the splanchnic output of IRI is well below that of C-peptide. It 
can be seen that the relative SGO is high $(72 \pm 16$ per cent) when a small dose of glucose $(12.5 \mathrm{~g})$ is administered. Relative SGO is however reduced when the oral dose of glucose is increased. The relative SGO reached its lowest value $(25 \pm 3$ per cent) upon an oral glucose load of $50 \mathrm{~g}$, and did not fall below 22 per cent even when the amount of ingested glucose was increased to $100 \mathrm{~g}$. For the entire group of subjects ingesting different oral glucose loads a direct linear correlation $(\mathrm{r}=0.82 ; \mathrm{p}<0.001 ; \mathrm{n}=$ 15) was observed between splanchnic glucose retention and the insulin production rate above basal (Figure 2).

\section{Discussion}

In the present study the effect of different oral glucose loads on splanchnic glucose exchange, and insulin and C-peptide release have been examined in healthy postabsorptive volunteers. Specifically, the studies were designed to study the fate of insulin across the splanchnic bed, and to determine both the escape of glucose from the splanchnic bed and its retention by the liver (= splanchnic glucose retention) following different amounts of ingested glucose.

Most of the information available on insulin metabolism is based either on experiments utilizing labelled insulin from various animal species $[21,22$, $23]$, or by studying the kinetics of the unlabelled hormone $[3,24]$.

Physiologically the cleavage of one molecule of proinsulin yields in the pancreatic B-cell one molecule of insulin and one molecule of connecting peptide. Both peptides are secreted into the portal blood in equimolar amounts $[13,25,26]$, and consequently traverse the hepatic bed. In this course about half the amount of insulin presented to the hepatic bed is extracted by the liver $[5,10,27]$. In contrast to insulin, C-peptide $[11,12,28]$ is removed only to a minor extent by the liver. The latter finding is based mainly on studies in rats $[11,28]$, whereas in lean normal weight pigs the reported hepatic extraction of C-peptide in the basal state was $19 \pm 2$ per cent [12]. In man studies of the metabolism of human C-peptide indicated that the kidneys are the major organ in C-peptide removal $[29,30]$.

However, the interrelationship of insulin and glucose metabolism in healthy man has been difficult to evaluate since direct measurements of insulin release into the portal blood are not readily available. Thus estimates of insulin release were obtained previously by using a model of the kinetics of insulin in man [3, $24]$. By this means and assuming 47 per cent for the hepatic extraction of insulin the calculated daily basal pancreatic production of insulin is $23.6 \pm 7.7$ units/ $1.73 \mathrm{~m}^{2}$. This implies that the pancreas contributes $16.3 \mathrm{mU} / \mathrm{min}$ to the portal vein under basal conditions [3]. This estimate compares with a reported basal secretory delivery rate of insulin to the general circulation via the hepatic veins of 12 units [1], of 14 units [2], and of 4-13 units [31] over a $24 \mathrm{~h}$ period. Given a $75 \pm 2$ per cent hepatic extraction rate of insulin as observed in our study the values for insulin release as reported by others were in part higher than those reported by this study.

First suggestions to estimate endogenous insulin production by determination of C-peptide levels were made by Rubenstein et al. [32]. Our investigations using this concept showed an insulin production rate of $17 \pm 2 \mathrm{mU} / \mathrm{min}$, which amounts to $24.5 \pm 2.9$ units $/ 24 \mathrm{~h}$ in the basal state, assuming a constant secretory rate and that no $C$-peptide was retained by the liver $[11,12,28]$. This compares well with a calculated insulin production rate of $23.6 \pm 7.7$ units/ $24 \mathrm{~h}$ reported by Sherwin et al. [3]. The basal posthepatic release of immunoreactive insulin was $5.5 \pm$ 0.48 units $/ 24 \mathrm{~h}$, corresponding to about 25 per cent of the IPR. This reflects an hepatic insulin extraction of 75 per cent (range 47-88 per cent) by healthy subjects in the basal state. Although this estimate of hepatic insulin extraction is somewhat greater than that observed by others $[7,8]$, it is still in the upper range of what has been reported experimentally [9]. It has however to be kept in mind that the estimates of the retention by the liver of insulin depend both on the precision of the calculated splanchnic insulin and C-peptide output, both of which rest on small differences in hepatic venous - arterial plasma concentrations. The proportion of insulin taken up by the liver of healthy subjects has also to be compared with the 40 per cent of endogenous insulin retained by the liver of patients with portacaval anastomoses [7]. Thus a high hepatic insulin uptake might even reflect a normal liver function.

Absolute amounts of insulin retained by the liver of our healthy volunteers rose in parallel with increasing glucose ingestion and insulin production rate. However, the mean extraction of insulin by the liver over the 2 hour period after an oral glucose load remained with one exception between 65 and $85 \%$, independent of the amount of ingested glucose. This is contrary to the suggestion of Field [33] that a greater fraction of insulin is extracted as greater amounts of insulin are presented to the liver.

The basal splanchnic glucose output of $126 \pm$ $7 \mathrm{mg} / \mathrm{min}$ or of $15.1 \pm 1.3 \mathrm{~g} / 2 \mathrm{~h}$ in this study compares favourably with $145 \pm 11 \mathrm{mg} / \mathrm{min}$ reported by others [34]. Our data indicate that following an oral glucose load the relative amount of glucose released 
by the liver ranges from 72 to $25 \%$ over the ensuing two hours depending on the amount of ingested glucose. The relative share of glucose released by the splanchnic bed was greatest following ingestion of $12.5 \mathrm{~g}$ of glucose, and smallest after an oral load in excess of $50 \mathrm{~g}$ glucose. Relative SGO did not fall below $22 \%$ even upon ingestion of $100 \mathrm{~g}$ of glucose which is consistent with the data of Felig et al. [34]. However, the relative share of ingested glucose retained by the splanchnic bed also rose with the size of the glucose load, reaching a maximum at an oral load of $50 \mathrm{~g}$. Splanchnic retention of ingested glucose was directly related to the estimated insulin production rate above basal levels (Figure 2). This is of great interest, since it is well known that the liver is a major site of insulin action in the control of glucose homeostasis $[34,35]$. Thus it is postulated that insulin is the signal for turning off glycogen breakdown and allowing glycogen synthesis to occur [35, 36, 37]. A glucose feedback on the liver has also been proposed, so that the correlation between the insulin production rate and the splanchnic retention of an oral glucose load could in part be related to different plasma glucose concentrations [38]. Similarily, it has been observed in normal man that in a state of acute insulin and glucagon deficiency hyperglycaemia per se can suppress splanchnic glucose output without inducing splanchnic glucose uptake [39]. Other studies in vivo however suggest that autoregulation of hepatic glucose output independent of insulin does not occur [35].

The main factor facilitating the adaptation of the splanchnic bed to retain a large share of an oral glucose load may be the direct delivery of insulin to the liver, with a higher concentration of insulin in portal as compared to peripheral blood [40]. Thus it has been observed in this study that even an eightfold rise in ingested glucose from $12.5 \mathrm{~g}$ to $100 \mathrm{~g}$ was only followed by an approximately 2.5 fold increase in SGO from $9.0 \pm 2.0 \mathrm{~g}$ to $24.7 \pm 1.0 \mathrm{~g}$. These data suggest that the liver, as the primary site of insulin action for the disposal of ingested glucose, protects peripheral tissues from extreme fluctuations in blood glucose (a) by retaining a greater percentage of a large glucose load, and (b) by providing a bigger relative share of an oral glucose load to peripheral tissues when only a tiny amount of glucose is ingested. Further studies are needed to understand the implications of our findings to pathological states.

Acknowledgements. The authors are grateful to Ms. A. Hofer and Ms. E. Nowotny for their valuable help in various aspects of this work. This study was supported in part by grant Nr. 3875 of the "Fonds zur Förderung der Wissenschaftlichen Forschung Österreichs".

\section{References}

1. Genuth, S. M.: Metabolic clearance of insulin in man. Diabetes 21, 1003-1012 (1972)

2. Turner, R.C., Grayburn, J.A., Newman, G. B., Nabarro, J. D. N.: Measurement of insulin delivery rate in man. J. Clin. Endocrinol. Metab. 33, 279-286 (1971)

3. Sherwin, R. S., Kramer, K. J., Tobin, J. D., Insel, P. A., Liljenquist, J. E., Berman, M., Andres, R.: A model of the kinetics of insulin in man. J. Clin. Invest. 53, 1481-1492 (1974)

4. Meythaler, F., Stahnke, E.: Die Wirkung des Pankreashormons bei experimenteller Umgehung der physiologischen Leberpassage. Arch. Exp. Pathol. 152, 185-197 (1930)

5. Madison, L. L., Kaplan, N.: The hepatic binding of I-131 labeled insulin in human subjects during a single transhepatic circulation. J. Lab. Clin. Med. 52, 927 (1958)

6. Mortimore, G. E., Tietze, F.: Studies on the mechanism of capture and degradation of insulin-I-131 by the cyclically perfused rat liver. Ann. N. Y. Acad. Sci. 82, 329-337 (1959)

7. Samols, E., Ryder, J. A.: Studies on tissue uptake of insulin in man using a differential immunoassay for endogenous and exogenous insulin. J. Clin. Invest. 40, 2092-2102 (1961)

8. Kaden, M., Curtin,R., Carey, L., Taylor, F., Field, J. B.: Evaluation of factors regulating hepatic extraction of insulin. Clin. Res. 19, 571 (1971)

9. Field, J. B.: Insulin extraction by the liver. In: Handbook of physiology. Steiner, D. F., Freinkel, N. (Eds.), Section 7, Vol. I, pp. 505-513. Am. Soc. of Physiology 1972

10. Camu, F.: Hepatic balances of glucose and insulin in response to physiological increments of endogenous insulin during glucose infusions in dogs. Eur. J. Clin. Invest. 5, 101-108 (1975)

11. Stoll, R. W., Touber, J. L., Menahan, L. A., Williams, R. H.: Clearance of porcine insulin, proinsulin, and connecting peptide by the isolated rat liver. Proc. Soc. Exp. Biol. Med. 133, 894-896 (1970)

12. Kühl, C., Faber, O. K., Hornnes, P., Jensen, S. L.: C-peptide metabolism and the liver. Diabetes 27 [Suppl. 1], 197-200 (1978)

13. Horwitz, D. L., Starr, J. I., Mako, M. E., Blackard, W. G., Rubenstein, A. H.: Proinsulin, insulin and C-peptide concentrations in human portal and peripheral blood. J. Clin. Invest. 55, 1278-1283 (1975)

14. Bratusch-Marrain, P., Björkman, O., Hagenfeldt, L., Waldhäusl, W., Wahren, J.: Influence of arginine on splanchnic glucose metabolism in man. Diabetes 28, 126-131 (1979)

15. Schmidt, F. H.: Methoden der Harn- und Blutzuckerbestimmung. In: Handbook of diabetes mellitus. Pfeiffer, E. F. (Ed.), Vol. II, pp. 913-946. München: J. F. Lehmanns 1971

16. Waldhäusl, W., Bratusch-Marrain, P., Dudczak, R., Deutsch, E.: The diabetogenic action of somatostatin in healthy subjects and in maturity onset diabetics. J. Clin. Endocrinol. Metab. 44, 876-883 (1977)

17. Rowell, L. B., Blackmon, J. R., Bruce, R. A.: Indocyanine green clearance and estimated hepatic blood flow during mild to maximal exercise in upright man. J. Clin. Invest. 43, $1677-1690$ (1964)

18. Bradley, S. E., Ingelfinger, E. J., Bradley, G. P., Curry, J. J.: The estimatation of hepatic blood flow in man. J. Clin. Invest. 24, 890-897 (1945)

19. Zahn, H., Klostermeyer, H.: Die Inselzellhormone: Chemie, Struktur und Synthese von Insulin. In: Handbook of diabetes mellitus. Pfeiffer, E. F. (Ed.), Vol. I, pp. 118-147. München: J. F. Lehmanns 1969

20. Oyer, P. E., Cho, S., Patterson, J. D., Steiner, D. F.: Studies on human proinsulin. Isolation and amino acid sequence of human pancreatic C-peptide. J. Biol. Chem. 246, 1375-1386 (1971) 
21. Berson, S. A., Yalow, R. S., Bauman, A., Rothschild, M. A., Newerly, K.: Insulin ${ }^{131}$ I-metabolism in human subjects: demonstration of insulin binding globulin in the circulation of insulin treated subjects. J. Clin. Invest. 35, 170-190 (1956)

22. Mirsky, I. A.: The metabolism of insulin. Diabetes 13, 225-229 (1964)

23. Ørskov, H., Christensen, N. J.: Plasma disappearance rate of injected human insulin in juvenile diabetic, maturity onset and non diabetic subjects. Diabetes 18, 653-659 (1969)

24. Sönksen, P. H., Tompkins, C. v., Srivastava, M. C., Nabarro, J.D. N.: A comparative study on the metabolism of human insulin and porcine proinsulin in man. Clin. Sci. Mol. Med. 45, 633-654 (1973)

25. Rubenstein, A. H., Clark, J. L., Melani, F., Steiner, D. F.: Secretion of proinsulin C-peptide by pancreatic B-cells and its circulation in blood. Nature 224, 697-699 (1969)

26. Heding, L. G., Larsen, U. D., Markussen, J., Jørgensen, K. H., Hallund, O.: Radioimmunoassays for human, pork and ox Cpeptides and related substances. Horm. Metab. Res. [Suppl.] 5, 40-44 (1974)

27. Kaden, M., Harding, P., Field, J. B.: Effect of intraduodenal glucose administration on hepatic extraction of insulin in the anesthetized dog. J. Clin. Invest. 52, 2016-2028 (1973)

28. Katz, A. I., Rubenstein, A. H.: Metabolism of proinsulin, insulin, and C-peptide in the rat. J. Clin. Invest. 52, 1113-1121 (1973)

29. Zilker, Th., Wiesinger, H., Ermler, R., Schweigart, U., Bottermann, P.: C-peptid Konzentration im Serum in Abhängigkeit von der Nierenfunktion. Klin. Wochenschr. 55, 471-474 (1977)

30. Faber, O. K., Kehlet, H., Madsbad, S., Binder, C.: Kinetics of human C-peptide in man. Diabetes 27 [Suppl. 1], 207-209 (1978)

31. Stern, M. P., Farquhar, J. W., Silvers, A., Reaven, G. M.: Insulin delivery rate into plasma in normal and diabetic subjects. J. Clin. Invest. 47, 1947-1957 (1968)

32. Rubenstein, A. H., Block, M. B., Starr, J, Melani, F., Steiner, D. F.: Proinsulin and C-peptide in blood. Diabetes 21 [Suppl. 2], 661-672 (1971)
33. Field, J. B.: Extraction of insulin by liver. Annu. Rev. Med. 24, 309-314 (1973)

34. Felig, P., Wahren, J., Hendler, R.: Influence of oral glucose ingestion on splanchnic glucose and gluconeogenic substrate metabolism in man. Diabetes 24, 468-475 (1975)

35. Madison, L. L.: Role of insulin in the hepatic handling of glucose. Arch. Intern. Med. 123, 284-292 (1969)

36. Bishop, J. S., Steele, R., Altszuler, N., Dunn, A., Bjerknes, C., DeBodo, R. C.: Effects of insulin on liver glycogen synthesis and breakdown in the dog. Am. J. Physiol. 208, 307-316 (1965)

37. Ishiwata, K., Hetenyi, G., Jr., Vranic, M.: Effect of D-glucose or D-ribose on the turnover of glucose in pancreatectomized dogs maintained on a matched intraportal infusion of insulin. Diabetes 18, 820-827 (1969)

38. Ruderman, N., Herrera, M. G.: Effect of extracellular glucose concentration on the net glucose production of perfused rat livers. Clin. Res. 14, 353 (1966)

39. Liljenquist, J. E., Mueller, G. L., Cherrington, A. D., Perry, J. M., Rabinowitz, D.: Hyperglycemia per se (insulin and glugacon withdrawn) can inhibit hepatic glucose production in man. J. Clin. Endocrinol. Metab. 48, 171-175 (1979)

40. Blackard, W. G., Nelson, N. C.: Portal and peripheral vein immunoreactive insulin concentrations before and after glucose infusion. Diabetes 19, 302-306 (1970)

Received: January 2, 1979,

and in revised form: May 25, 1979

Dr. W. Waldhäusl

1. Medizinische Universitätsklinik

Abteilung für klinische Endokrinologie

und Diabetes Mellitus

Lazarettgasse 14

A-1090 Wien

Austria 